\title{
THE INTERNATIONAL COMMUNITY'S METHODS OF SUPPORTING STATES TO SOLVE REFUGEE PROBLEMS
}

\author{
A.N. Al-Zubaidi \\ Peoples' Friendship University of Russia (RUDN University) \\ Miklukho-Maklaya str., 6, Moscow, Russian Federation, 117198
}

\begin{abstract}
This article looks into solutions offered by the international community to the countries suffering from a constant influx of refugees and which require international assistance. Refugee migration is a type of forced migration. Since the introduction of international refugee law, the international community has been using one of the three solutions to the refugee problem: voluntary repatriation, local integration and resettlement in a third country. The article regards resettlement in a third country as the main solution to the global refugee problem, which should be used on a large scale. The article also reviews the cases of interference in the developing countries' internal affairs and the role of such interference in aggravating the refugee problem. Despite the benevolence of the intentions, such as the protection of the refugees' human rights, this intervention demonstrated the opposite effect in certain cases in Iraq, Afghanistan and Libya. Consequently, the author touches upon the importance of the peaceful ways in solving and preventing the problem of refugees. Finally, the article points out the international community's new approach to the problem: integration of development projects and refugee support programs in countries needing this type of assistance.
\end{abstract}

Key words: refugees, resettlement in a third country, intervention in the internal affairs, integration of development and assistance

The article analyzes solutions offered by the global community to the countries suffering from a constant influx of refugees and requiring international assistance. Refugee migration is a type of forced migration. There are three main international documents regulating the rules of the right of asylum: the 1951 United Nations Convention on the Status of Refugees, the 1966 General Protocol on the Status of Refugees, and the 1966 United Nations Declaration on Regional Refuge [6. P. 13-13].

The definitions of "refugee", offered by certain international organizations, vary in different documents. Most of them include "migration caused by armed conflict". The 1969 OAU Convention added "migration caused by natural disaster" to the definition. Before we proceed with the analysis of traditional solutions to the refugee problem, we intend to discuss other countries' responsibilities in regards to the protection of refugees [4. P. 14].

It is direct responsibility of other countries, including the country of origin of the refugee, to recognize the right of the refugee to lawfully reside in the territory of the host country. The host country shall refrain from displaying any acts of hostility towards the refugee staying on its territory [11. P. 124].

The host state should be committed to the rules of international humanitarian law, international human rights law and international refugee protection law. Host countries and communities often emphasize the burden associated with refugee protection. If this burden exceeded the host country's capacity, the rules of justice at the international level come into action. One of the main sources of international law adopted by civilized 
nations is the International Court of Justice. While the domestic principles of law differ from country to country, whether they are agreed upon or not among the nations, the international rules of justice must apply to every member of the global community [8. P. 24].

This leads to the conclusion that the international conventions on refugees impose obligations on the state of asylum — in a lot of cases a neighboring country but do not establish any responsibility for the states that are territorially out of the asylum seeker's reach. The most important of these documents is the 1951 United Nations Convention on the Rights of Refugees, in particular its article 33, in which the Convention restricts the authority of the state of refuge to expel a refugee and return them to a country where their life, right to freedom of thought, conscience, and religion is threatened. In view of the importance of this article, no modifications to its main provisions are allowed to be made [2. P. 67].

The state of affairs when the neighboring host state is bound by its obligations to the refugee, but other countries bear no responsibilities, seems to be quite illogical, because these international rules leave refugees with a single option: seek asylum in a neighboring country, with no other alternatives. Once a refugee moves out of the zone of danger and is accepted by the host country, they become a burden for the country granting them asylum, as it is obliged to provide all the necessary conditions for their life on its territory. First asylum countries cannot prevent refugees from seeking asylum on their territory and, according to international refugee law, they cannon restrict refugees' freedoms. Thus, the more powerful states, economically more fit for providing shelter for those who seek it, shift the responsibility on developing countries, that lack necessary facilities. A lot of host countries have no choice but accommodate refugees in camps. The need for more equitable rules of sharing the responsibilities for hosting refugees is apparent. Meanwhile, the poorer countries have been forced to monitor their borders under the pretext of protection against terrorism in order to prevent the influx of refugees.

The authority of the International Court of Justice does not include prosecution against states on charges of neglecting their international obligations on human rights issues. It settles legal disputes between member states; meanwhile, it seems reasonable to broaden its jurisdiction by letting it deal with human rights violations at the international level, including refugee rights, same as the European Court Of Human Rights does it on the regional level.

Domestic administrative law relies on the contingency theory, which is based on the presumption of administrative relations being regulated by a contract made between the administration and an individual who performs a public service. If the benefits from this contract for one of the parties outweigh those for the other, the contract becomes a burden for the disadvantaged party. The judge balances the contract and the administration bears part of the expenses. This theory is based on the idea of the general facility, according to the jurisprudence of administrative law [3. P. 634].

Taking into consideration the difference between domestic and international law, the author would like to point out that the state cannot, in many cases, abide by its agreements because of their idealistic requirements, or for other reasons beyond its capacity. It is up to the international community to work out a system of adequate principles regulating administrative relations between states. 


\section{THE ADVANTAGES OF THIRD COUNTRY RESETTLEMENT AS COMPARED TO OTHER TRADITIONAL SOLUTIONS}

Since the introduction of international refugee law, the international community has been using one of the three solutions to the refugee problem: voluntary repatriation, local integration and resettlement in a third country. For many years, the global community has been failing to seek preventive rather than remedial solutions, which can be attributed to the Cold War period. The author questioned the effectiveness of the old traditional solutions and found that voluntary repatriation is, in fact, not an effective solution. Voluntary repatriation presupposes international intervention in order to facilitate a refugee's return to their country of origin and provide assistance to them. Usually voluntary return programs take time, as the refugees have to wait for the risks and dangers in their country of origin to be fully removed before returning home. The second solution is integration into the country of asylum. This solution may cause two problems for the state that integrates the refugees. The first problem is related to the cultural identity of the state. Lebanon, for example, refuses to provide shelter for Palestinian refugees and even tries to deport them for fear of the sectarian imbalance (Christian-Sunni-Shiite-Druze). The second problem is of an economic nature, as the resettlement of refugees affects the host country's economic structure. Therefore these solutions should be considered outdated, and a new alternative must be found.

The author believes that the third solution - third country resettlement - is a logical and effective method, which should be used on a large scale to solve the problem of refugees. However, the international community which offered the solution, has not been doing much in the way of its implementation. According to statistics, $86 \%$ of the world's refugees come mainly from the Middle East, Africa and South Asia. Only 3\% of Syrian refugees live outside of Turkey, Jordan, Lebanon and Egypt. After the right of asylum in Europe was granted in 2016, there has not been a significant change in statistics due to the low rate of acceptance of refugees from outside of Europe [5].

The author sees third country resettlement as the most appropriate and durable solution, because it is in line with the nature of the universe and the humanitarian system, as well as human rights recognized by nations. Article 13/1 of the Universal Declaration of Human Rights states: "Everyone has the right to leave any country, including his own, and has the right to return to it".

The arguments previously made by certain nations in order to prevent the equitable distribution of refugees are baseless, although they have had some authority in the past. Today they are regarded as completely unfounded. One of such arguments stated that the long-distance transfer of refugees is costly. Another insisted that it is unfavorable for a refugee to leave their cultural environment and might become inconvenient for the receiving country. However, one can hardly argue that global sharing of responsibilities for refugee protection and support is the most reasonable decision. Previously a regional issue, the problem of refugees has become global. While the resettlement of refugees in poor communities can lead to civil wars, their fair distribution is the key to solving the existing problem. 


\section{THE EFFECTIVENESS OF INTERVENTION IN INTERNAL AFFAIRS} IN SOLVING THE REFUGEE PROBLEM

In the twentieth century, the idea of resettlement in a third state was not popular with developed countries, which were preventing it from spreading and tried to keep focus on the other two conventional options. With the end of the Cold War and the 20th century, the balance of power in the world had shifted. After the collapse of the Soviet Union, the world had become monopolistic rather than bipolar. It has been reflected in the United States' respect for the United Nations and adherence to its Charter, which emphasizes respect for the internal sovereignty of states and the principle of equality of sovereignty. As is stated in Article 2/7 of the Charter, "Nothing in this Charter shall authorize the United Nations to intervene in matters which are essentially within the domestic jurisdiction of a state". Since the United States is a signatory to the Charter, it must abide by its provision of non-interference in the internal affairs of states. However, the United States has not been compliant with its pledge. Examples of recent U.S. and European intervention include interference in Iraq, Afghanistan, and Libya without any real legal justification, according to international law officials in the East and West [9].

The only kind of intervention permitted by international law is the intervention acquired through the United Nations' legal authorization. The United Nations Charter allows only two cases of permissible interference: the case of legitimate defense and security Collective [1].

Interference in other states' domestic affairs outside of the United Nations' authorization is not only inhumane, but also truly a humanitarian catastrophe. Spreading violence and destruction, hegemonic powers, whether the United States or Europe, deprive countries of security and show utter disrespect for human rights. The author is going to analyze three cases of intervention in other states' internal affairs: Afghanistan, Iraq and Libya.

\section{US Intervention in Afghanistan}

Following the attacks on the World Trade Center on September 11, 2001, the United Nations Security Council issued Resolution 1368, condemning the attack as an act of terrorism and a threat to international peace and security. On September 28, 2001, The UNSC adopted Resolution 1373, as a counter-terrorism measure against the perpetrators and the countries suspected of assisting the terrorists. Afghanistan agreed to extradite Osama bin Laden on the condition that he must be tried outside of the U.S. Meanwhile, bin Laden was given the right to leave Afghanistan voluntarily, to which Washington responded by sending troops and building alliances [9. P. 213].

The above-mentioned UN Security Council resolutions prohibit any kind of forced military presence in any sovereign state, and Afghanistan is not an exception. Regardless of the legal dispute in this matter, the United States, nonetheless, claims its right to legitimate defense. Claiming, that the goal of the intervention is to free the Afghan people and protect human rights, George W Bush launches operation "Enduring Freedom" in Afghanistan. As a result of the war in Afghanistan, the number of Afghan refugees reached 3.5 million people, with 1.9 million "displaced" and 1.4 million "stateless" persons, ranking Afghanistan as the country with the most refugees in Asia [14]. 


\section{Invasion of Iraq}

As a response to the occupation of Kuwait by Iraq on August 2, 1990, the UN Security Council issued Resolution 687 on April 2, 1990, imposing an economic embargo on Iraq. After that, the United States proceeded to look for reasons to justify military intervention in Iraq, namely Iraq's possession of weapons of mass destruction, as well as the necessity to liberate the Iraqi people from dictatorship and replace the current regime with a democratic system. Iraq's relationship with al-Qaeda was also casually alluded to [9. P. 215]

The United States and Britain embraced what they called "pre-emptive war" as a military doctrine at the time, claiming that Iraq possesses weapons of mass destruction (WMDs), which is prohibited by the Security Council's resolution. The United States proceeded to bomb strategic locations in Iraq; consequently, however, the United States' intention to disarm Iraq of WMDs changed into the goal of overthrowing Saddam Hussein's regime, going beyond the previous expectations. To achieve this goal, in 2002, Security Council adopted resolution 1441, which presented a threat to Iraq, as it was given a deadline to comply with its "disarmament obligations" and let the international inspectors back in. After a number of disagreements between Iraq and the inspectors, and although Iraq still had some time before the end of the deadline, the United States decided to proceed with the intervention, justifying their actions with the previous resolutions [10. P. 276].

The United States invoked the protection of human rights to justify its intervention in Iraq. Hiding behind noble intentions, what has Washington effectively achieved? The result is the violation of human rights of over 750,000 Iraqi refugees seeking shelter in Jordan and other countries.

\section{Intervention in Libya}

After years of tug-of-war between Libya and the West, Libya was accused of bombing a US airliner in 1988 and a French airplane in 1989. As a result, in 1992, United Nations adopted Resolution 731, imposing sanctions on Libya. The sanctions were lifted by the Security Council's Resolution 1506 of September 12, 2003 in exchange for the extradition of the accused.

A few years after that conflict, in February 2011, concurrent with rallies in several Arab capitals, Western countries began to criticize Libya, calling its practice of "shedding blood" unacceptable and the events occurring in Libya "shameful and inhumane". Western nations started to discuss their options of dealing with the Libyan crisis. Suggestions included the imposition of a no-fly zone over Libya, which required the destruction of Libyan air forces.

The League of Arab States suspended Libya's membership on February 23, 2011 and called on the Security Council to impose a no-fly zone over Libya. The British Prime Minister, backed up by the French Foreign Minister, also appealed to the Security Council to issue a comprehensive resolution on Libya. The NATO intervention required a regional and international reference. The regional reference was provided, and subsequently the Security Council issued resolutions 1970 and 1973/2011. They included referral of the situation in Libya to the International Criminal Court, arms and travel ban, freezing of Libyan assets and establishment of a no-fly zone over Libya. 
NATO's mission was to enforce a no-fly zone and secure humanitarian aid in Libya, however, it went beyond its alleged mission and carried on with bombing Libyan civilian and military sites. Gaddafi's regime was notoriously flagitious; yet, no such measures were taken in relation to other countries where similar violations occurred. Nothing prevented the Security Council from adopting such resolutions in the cases of Gaza and Rwanda; however, none were issued. According to some opinions, intervention in Libya was a "revenge" under a humanitarian cover.

The report, prepared on September 4, 2014 by the United Nations Support Mission in Libya in cooperation with the Office of the United Nations High Commissioner for Human Rights, gives rough estimates of the post-intervention refugee situation in Libya: at least 100,000 Libyans became displaced after the fighting following the fall of Gaddafi's regime, while about 150,000 citizens fled from the country [12. P. 134].

Military intervention under a humanitarian cover does not only stimulate the influx of refugees to a country of asylum, it is also unacceptable for two reasons:

- Numerous civilian casualties resulting from bombing inaccurately targeted areas;

- The weakening of the political regime, creating a state of chaos, in which terrorist groups proliferate.

\section{SOLVING THE PROBLEM OF REFUGEES BY PEACEFUL METHODS}

The influx of refugees happens mainly due to the persecution by the government of their own citizenry, or internal or international armed conflicts, resulting in the flight of refugees from the areas of conflict and danger to safer areas outside the country. Internal conflicts usually involve armed militias, not affiliated with any state but covertly financed by one or several countries. Whether the conflict is civil or international, the international community can use peaceful means to resolve these disputes. In the case of government persecution of certain groups of people, the Security Council has the right to initiate proceedings in the International Criminal Court in accordance with article 13 of the Rome Statute of 1998. If a certain case does not lie within the ICC's jurisdiction, the international community has the right to address the UN Security Council in order to impose economic sanctions on the state where the persecution happened. Military intervention, however, as has been proven above, may not be considered an efficient solution to the problem ${ }^{1}$.

1 Article 5 of the Rome Statute of 1998 states: " 1 . The jurisdiction of the Court shall be limited to the most serious crimes of concern to the international community as a whole. The Court shall have the power to consider the following offenses:

(A) The crime of genocide;

(B) Crimes against humanity;

(C) War crimes;

(D) The crime of aggression".

Article 13 of the Rome Statute of 1998 provides: "The Court may exercise its jurisdiction with respect to an offense referred to in article 5 in accordance with the provisions of this Statute in the following cases:

(A) If a State Party refers to the Prosecutor in accordance with article 14 a situation in which one or more of the offenses appears to have been committed;

(B) If the Security Council, acting under Chapter VII of the Charter of the United Nations, refers a case to the Prosecutor, in which it appears that one or more of these crimes has been committed...". 
Chapter VI of the United Nations Charter deals with peaceful settlement of disputes between states. Article 33 of the Charter states: " 1 . The parties to any dispute whose continuation would endanger the maintenance of international peace and security shall seek to resolve it. First and foremost through negotiation, investigation, mediation, conciliation, arbitration and judicial settlement, or to resort to regional agencies or arrangements or other peaceful methods of their choice. 2. The Security Council shall call upon the parties to the conflict to resolve their dispute by such methods if they deem it necessary".

National unity is still the only cornerstone of stopping bloodshed. Social thinkers say civil war never ends, except in one case: national reconciliation. If war continues, one side will destroy the other, and both sides will sustain irreparable losses. Meanwhile, the efforts and expenses could be used for peaceful purposes in order to contribute to the prosperity of the state. Thus, reconciliation through peaceful means is the only effective way of solving civil conflicts [7].

What applies to a civil war applies to an international war as well. Take, for instance, Europe: the Second World War, among other horrific conflicts that were being waged there throughout history, left the continent devastated. The reasons for those wars mostly originated from ideological and ethnological intolerance. Today European countries are among the strongest powers in the world, using peaceful ways of resolving conflicts, such as negotiation and collaboration. Meanwhile, one needs to remember that the largest numbers of refugees in history were born as a result of two major wars that happened on the territory of Europe.

The UN Charter gives the Security Council primary responsibility for the maintenance of international peace and security. In fulfilling this responsibility, the Council can establish a UN peacekeeping operation. These operations have traditionally been associated with Chapter VI. This is how the Chapter describes them: "United Nations operations contain a group of civilians and military personnel, working with the consent of the disputing parties and impartially; they perform the paramilitary functions of civil works for the restoration of peace and help countries under conflict and war. These functions include the implementation of peace agreements, provision of security and stability, promotion of the rule of law, work on realization of human rights, and electoral assistance". The Charter of the United Nations contains no explicit reference to peacekeeping operations, which has caused some dispute among the specialists in international law. Chapter VI of the Special Charter, which deals with resolving disputes by peaceful means, is considered to be the legal basis for the work of the international peacekeeping force. Article 36 of the Chapter clarifies: "The Security Council in any stage of conflict of the kind referred to in article 33 or a similar position is authorized to recommend such procedures and methods of settlement as it deems appropriate." Article 33 refers to the means of solving a dispute which "would not endanger the maintenance of international peace and security". Article 40 of Chapter VII is also viewed as the legal basis for authorizing the deployment of UN peacekeeping operations. What is important, however, is the existence of such operations.

The role of peacekeeping operations appears to be complementary to the role of peaceful methods of conflict resolution. Among the peacebuilding activities, there are 
those that directly or indirectly contribute to the protection of refugees. The following are the most important examples of UN peacekeeping operations:

1. Monitoring of ceasefire: In 1999, the Security Council deployed a peacekeeping operation in the Democratic Republic of the Congo under resolution 1279. By observing the ceasefire, the peacekeeping personnel played a key part in resolving the internal armed conflict initiated by rebel movements.

2. Disarmament and demining: International peace-keeping missions, approved by UN Security Council resolution 1769 (2007), played an important role in bringing stability to the war-torn Darfur region of Sudan. The peacekeepers disarmed militias in Darfur and contributed to limiting arms procurement to the country.

3. Protection of areas of internal conflict: The United Nations peacekeeping forces have made significant progress in United Nations-sponsored areas, such as Cyprus, Kosovo and East Timor. Considerable achievements have been made in the areas of promoting national security, crisis prevention, democratization, and peaceful conflict resolution. UN peacekeepers offer training courses on the protection of civilians from violence, including refugee protection. They also support the restoration and extension of state authority and prosecute perpetrators of war crimes and crimes against humanity, such as in Darfur, for the purpose of promoting justice and human rights.

4. Electoral assistance: Peacekeeping forces made a significant contribution to organizing fair elections in Afghanistan, Côte d'Ivoire, Liberia, Sudan, Kosovo and East Timor.

5. National reconciliation: UN peacekeepers assisted in establishing national reconciliation in many countries, including the Democratic Republic of the Congo, by initiating negotiations between the conflicting parties [7. P. 133-136].

6. Support for the rule of law: The peacekeeping operations deployed in Liberia are a good example of the UN peacekeepers' work towards strengthening the rule of law. UN civil personnel assisted in establishing an integrated national legal framework via judicial reform and other rule-of-law related activities.

7. Assistance in voluntary repatriation: Peacekeepers protect returnees against harassment, verbal or physical harm, discriminatory arrests and other violations of the refugees' human rights upon their voluntary return to the country of origin [6. P. 136].

\section{DEVELOPMENTAL AID FOR POOR COUNTRIES AS A SOLUTION FOR REFUGEES}

From 2011 until the end of 2017, the Syrian crisis was one of the greatest political, humanitarian and developmental challenges of the present. Threatening the civil population of both Syria and its neighboring countries and thus requiring an urgent action from global organizations, it drove the international community to change its mindset and come up with a collective response. The United Nations Development Program (UNDP) has been at the forefront of new initiatives. Promoting cooperation among nations, UNDP focuses on crisis response and recovery by addressing both the humanitarian and development aspects of the crisis in a coordinated manner through sustained responses under national leadership. 
The United Nations, with the help of UNDP and the United Nations High Commissioner for Refugees (UNHCR), launched the Regional Refugee and Resilience Plan (3RP) in December 2014, which was the first model of integrating humanitarian and development resources into a single framework in order to meet the needs of refugees and their host communities. Along with humanitarian assistance, the support of host communities requires sustainable development measures. This new approach was revised and successfully approved in February 2016 at a conference in London. A natural response to the complexity of the Syrian crisis, the 3RP is aimed at expanding sources of humanitarian funding and implementing long-term development goals ${ }^{2}$ [13. P. 3].

Only through investment in sustainable solutions will the international community be able to help solve the refugee problem in Jordan, Lebanon, Egypt and other countries. Such long-term measures demonstrate great results through capacity-building by utilizing the local environment, technology, education and other resources. It is a more integrated approach, given the massive number of refugees. Such an approach renders sustainable financial support to refugees, local communities and governments by promoting the transition to the new infrastructure and increasing employment opportunities and human resources.

The agreement reached by the developing countries at the donors' conference in London in 2016 was the global community's biggest step towards the integration of development and refugee protection plans in such countries. However, the international community turned a blind eye to the tragedy of the Yemeni people, after the economic blockade imposed Yemen put its people on the poverty line, leaving millions homeless and displaced.

The international community must adopt different policies on the protection of refugees by means of enacting new laws, drawing global attention to the refugee problem and promoting resettlement of those displaced in territorially more distant countries. In order to develop a new law on refugees, as well as mechanisms of its implementation, new international conferences on refugee issues should be held, followed by a global agreement. The refugee problem should be regarded as a high priority issue, and it is our hope that global efforts directed to this problem will help solve it once and for all.

\section{REFERENCES}

[1] Al-Nazir S., Al-Khalifa A. Humanitarian Intervention but Its Legitimacy and Types. Journal of Justice (Ministry of Justice — Sudan). 2013; 38.

[2] Al-Rashidi A. The Right to Seek Asylum as a Human Rights Application, a Comparative Study in the Light of International Covenants and Some Constitutions and Arab Legislation: Symposium on International Protection of Refugees. Center for Research and Political Studies, Faculty of Economics and Political Science, Cairo University, 17-18 November 1996: 67.

2 "What I would like to tell you is that the issue of refugees may be a humanitarian issue. It starts as a humanitarian issue, but it has a direct relationship to development issues and there is no need to separate the humanitarian and development aspects, they are all part of development issues". UN Secretary-General Ban Ki-moon said on 1 October 2014. 
[3] Al-Tamawi S. The General Principles of Administrative Contracts. Cairo: Dar Al-Fikr; 2005: 634.

[4] AL-Zubaidi A.N. The State's Ability to Commit to the Legal Protection of Refugees. Master Thesis. Jordan: Jadra University: 14.1.

[5] Amnesty International Website. 8 Ways to Resolve the Global Refugee Crisis. Available from: https://www.amnesty.org. Accessed: 11.02.2018.

[6] Astiah F. Asylum in the Jordanian and International Law (Legal Comparative Study). Master Thesis. Amman: Amman Arab University; 2014. 38 p.

[7] Dimitri A. National Reconciliation Duty and Responsibility. The Writer - Egypt. 1973; Vol. $13 ; 143$.

[8] Gillard Van G. Law Among Nations: An Introduction to International Public Law (Part I). Beirut: New Horizons Publishing House; 1970: 24.

[9] Jumaili A.S.H. Intervention in the Occupation: A Proposed Term under International Law. Rafidain. 2013; 56.

[10] Khalil J. The Legitimacy of the Use of Force in International Relations Applied on US Policy Toward Iraq, the Years 1990-2003. Financial and Commercial Research Journal (Faculty of Commerce, University of Port Said). 2008; 2: 276.

[11] Mahmoud R.Y. Sharing Responsibility for Refugees and Respect for International Law. Al-Manara Journal for Legal and Administrative Studies. Morocco; 2017: 124.

[12] Sheikh Mohammed A.H. The Dimensions of Humanitarian Intervention of the United Nations in the Events of the Arab Revolutions: Libya and Syria, a Model. The Arab Journal of Political Science. 2014; 44-43: 134.

[13] UNDP. Capacity Building for Crisis Response: Response to the Syrian Crisis. UNDP. 11.03.2015: 3 .

[14] UNHCR. Where we Work: Asia and the Pacific. UNHCR. Available from: http://www.unhcrarabic.org/pages/4be7cc27916.html. Accessed:11.2.2018.

\title{
МЕТОДЫ МЕЖДУНАРОДНОГО СООБЩЕСТВА ПО ОКАЗАНИЮ ПОДДЕРЖКИ ГОСУДАРСТВАМ В РЕШЕНИИ ПРОБЛЕМ БЕЖЕНЦЕВ
}

\author{
А.Н.М. Альзубейди \\ Российский университет дружбы народов \\ ул. Миклухо-Маклая, 6, Москва, Россия, 117198
}

В данной статье рассматриваются решения, предлагаемые международным сообществом странам, страдающим от постоянного притока беженцев и нуждающимся в международной помощи. Миграция беженцев является одним из видов вынужденной миграции. После введения международно-правового статуса беженцев международное сообщество использует одно из трех решений проблемы беженцев: добровольную репатриацию, местную интеграцию и расселение в третьей стране. В статье рассматривается расселение в третьи страны как основное решение глобальной проблемы беженцев, которое должно быть использовано в больших масштабах.

В статье также рассмотрены случаи вмешательства во внутренние дела развивающихся стран и роль такого вмешательства в обострении проблемы беженцев. Несмотря на благожелательность намерений, таких, как защита прав человека, эти интервенции в некоторых случаях продемонстрировали обратный эффект, например в Ираке, Афганистане и Ливии. 
Автор затрагивает важность мирных путей решения и предотвращения проблемы беженцев. Также в статье отмечается новый подход международного сообщества к проблеме беженцев: интеграция проектов развития и программ поддержки беженцев в странах, нуждающихся в этом виде помощи.

Ключевые слова: беженцы, переселение в третью страну, вмешательство во внутренние дела, интеграция развития и помощи

\section{Сведения об авторе:}

Ахмед Нидаль Мохаммед Альзубейди - аспирант кафедры сравнительной политологии Российского университета дружбы народов (Иордания) (e-mail: zbaidy22@gmail.com).

\section{Information about the author:}

Ahmed Nidal Al-Zubaidi — Postgraduate Student of the Department of Comparative Politics, Peoples' Friendship University of Russia (RUDN University) (Jordan) (e-mail: zbaidy22@gmail.com).

Статья поступила в редакцию 15.05.2018.

Received 15.05.2018. 